\title{
Fé cristã, racionalidade e o "sentido do mundo" 20 anos após o \\ 11 de setembro
}

\section{Christian faith, rationality and the "sense of the world" 20 years after $9 / 11$}

Vinte anos após o 11 de setembro, faz-se necessário refletir acerca das consequências deste acontecimento para todo o globo. O "sentido do mundo" dado pela fé cristã e pela racionalidade ocidental, ainda que permaneça como preponderante, precisa reconhecer a emergência de outras duas culturas: a asiática e a islâmica. A interculturalidade, segundo Joseph Ratzinger, coloca-se como exigência para a convivência plural. Na atual política internacional do Papa Francisco, em seu empenho por uma cultura do encontro e do diálogo, é possível verificar em suas atitudes, gestos que demonstrem a importância da aproximação entre ocidente e oriente protagonizados pelo catolicismo e islamismo.

Palavras-chave: 11 de setembro. Diálogo. Fé cristã. Interculturalidade. Racionalidade.

\section{Abstract}

Twenty years after 9/11 it is necessary to reflect on the consequences of this event for the entire globe. The "sense of the world" given by the Christian faith and Western rationality, although it remains the great sense of the world, needs to recognize the emergence of two other cultures: Asian and Islamic. Interculturality, according to Joseph Ratzinger, is a requirement for plural coexistence. In the current international policy of Pope Francis, in his commitment to a culture of meeting dialogue, it is possible to verify in his attitudes, gestures that demonstrate the importance of the rapprochement between the West and the East, led by Catholicism and Islam.

Keywords: September $11^{\text {th }}$. Dialogue. Christian faith. Interculturality. Rationality.

\section{I n t rod u ção}

Ao fazer memória dos 20 anos do acontecimento da queda das torres do World Trade Center e do ataque ao Pentágono, nos Estados Unidos, no dia 11 de setembro de 2001, é importante recordar que a tragédia, infelizmente, deixou muitas pessoas mortas, tornou-se emblemática e expressou, entre

1 Pontifícia Universidade Católica de Campinas (PUC-Campinas), Centro de Ciências Humanas e Sociais Aplicadas, Faculdade de Teologia. R. Professor Dr. Euryclides de Jesus Zerbini, 1516, Parque Rural Fazenda Santa Cândida, 13087-571, Campinas, SP, Brasil. E-mail: <joseboareto@puc-campinas.edu.br> 
tantos significados, uma situação de influência norte-americana junto ao Oriente Médio - que pode ser entendida como uma relação de oposição "Império" e novos "bárbaros", considerando o processo de globalização e da própria ordem mundial². Mas esse acontecimento também traz uma reflexão para a própria ciência da religião, pois a partir do 11 de setembro, tornou-se mais evidente que o processo de globalização ainda mantém "o sentido do mundo" a partir das duas grandes culturas ocidentais: a fé cristã e a racionalidade, e estas, por mais que tenham a pretensão de serem universais, não o são, e muitas vezes o projeto ético proposto por elas permanece como uma abstração³.

Isto não significa que se deva abandonar o diálogo com as outras culturas que emergem, mas encontrar pontos de convergência. Reconhecer que a cultura ocidental não é a única no globo é fundamental e, justamente, é esta uma questão para nós, pois é preciso refletir sobre a interculturalidade, representada em particular por duas culturas emergentes: asiática e islâmica ${ }^{4}$. 20 anos após o 11 de setembro, propõe-se compreender os processos dialógicos que estão sendo protagonizados pela lgreja Católica e o Islamismo 5 . Por exemplo, o encontro entre o atual pontificado do Papa Francisco e o Grande Imã Ahmad al-tayyeb oferece-nos condições para compreender que numa cultura do encontro é possível descobrir caminhos, não só para as religiões, mas para as sociedades em sua interculturalidade, para uma convivência plural - o desafio deste século.

Pretendemos, com este artigo, primeiramente, analisar a leitura do ex-embaixador do Brasil nos Estados Unidos, Rubem Antônio Barbosa, sobre o que representou o 11 de setembro de 2001. Em seguida, refletir sobre o "sentido do mundo" pós 11 de setembro, considerando o pensamento de Jurgen Habermas e Joseph Ratzinger, em suas provocações filosóficas e teológicas, no debate sobre razão e religião, denominado "Dialética da secularização". E, por fim, concluiremos com uma reflexão sobre a declaração conjunta por uma cultura do diálogo assinada pelo Papa Francisco e o Grande Imã Ahmad

\footnotetext{
2 Rubens Antônio Barbosa, ex-embaixador do Brasil nos Estados Unidos, em seu artigo intitulado "Os Estados Unidos pós 11 de setembro de 2001 : implicações para a ordem mundial e para o Brasil", procura oferecer uma leitura sobre os atentados de 11 de setembro de 2001 , considerando o alcance do poderio norte-americano neste contexto. Para isto, utiliza-se do binômio "Império" e novos "bárbaros" para fundamentar sua reflexão. Diz o autor: "Os atentados de 11 de setembro de ocorrem no momento em que os EUA, superados os obstáculos da Guerra Fria e somado o crescimento acumulado ao longo dos 10 anos de boom econômico, atingem a plena maturidade de seu poderio e ocupam um lugar no panteão das potências mundiais só comparável à Roma Imperial. [...] A ação contra o World Trade Center e o Pentágono, centros nevrálgicos (e simbólicos) do poderio americano, vai buscar suas origens no outro lado do fenômeno analisado por Hardt e Negri: o território dos excluídos do Império - 'os bárbaros' (ou 'novos bárbaros', na opinião de Jean Christophe Ruffin)" (Barbosa, 2002, p. 73).

3 "O sentido do mundo" é uma alusão a compreensão oferecida por Joseph Ratzinger em seu debate com Jurgen Habermas intitulado "Dialética da secularização" em torno da reflexão sobre a interculturalidade. Para Ratzinger: "A interculturalidade me parece ser hoje uma dimensão que não pode faltar na discussão sobre as questões básicas da condição humana. Ela não pode ficar restrita ao interior do cristianismo, nem à tradição racionalista do ocidente, apesar de ambos se considerarem universais em seu autoconceito, e talvez de iure o sejam. Mas de fato ambos precisam reconhecer que são aceitos e compreendidos somente em algumas partes da humanidade". [...] "Com outras palavras, aquela fórmula universal, racional ou ética ou religiosa, que seja aceita por todos e que poderia sustentar o todo, não existe. Pelo menos no momento atual, ela não é alcançável. Por isso, também o assim denominado etos mundial continua sendo apenas uma abstração" (Habermas; Ratzinger, 2007, p. 82).
}

${ }^{4}$ Ainda sobre a temática da interculturalidade faz-se necessário reconhecer o que diz Joseph Ratzinger: "Inicialmente é importante constatar que já não existe uniformidade dentro dos espaços culturais, ao contrário, todos trazem a marca de tensões profundas dentro de sua própria tradição cultural. No ocidente, essa situação salta aos olhos. Mesmo que a cultura secular de uma racionalidade rigorosa, da qual Jurgen Habermas acaba de desenhar um retrato impressionante, predomine em larga escala e se entenda como seu elo de união, a interpretação cristã da realidade continua presente como força efetiva. Os dois pólos se relacionam numa tensão e proximidade variáveis, dispostos a aprender com o outro e, ao mesmo tempo, rejeitando-se com mais ou menos intensidade. O espaço cultural islâmico traz a marca de tensões semelhantes: um leque amplo se estende desde o absolutismo fanático de figuras como Bin Laden até as atitudes abertas a uma racionalidade tolerante. 0 terceiro grande espaço cultural, a cultura indiana ou, melhor dizendo, os espaços culturais do hinduísmo e do budismo, apresenta as marcas das tensões semelhantes, mesmo que estas, à primeira vista, mostrem-se menos dramáticas. Essas culturas também se veem confrontadas tanto com as pretensões do racionalismo ocidental quanto com os apelos da fé cristã, ambos presentes em seu meio" (Habermas; Ratzinger, 2007, p. 83).

5 De 3 a 5 de fevereiro de 2019, o Papa Francisco fez sua viagem apostólica aos Emirados Árabes Unidos. Lá ele e o Grande Imã Ahmad al-tayyeb assinaram uma "Declaração sobre a fraternidade". Sobre esta viagem, dando entrevista aos jornalistas no voo, ele disse: "O documento foi preparado com muita reflexão e também oração. Tanto o Grão Imame com a sua equipe, quanto eu com a minha, rezamos muito para fazer este documento. Para mim existe somente um grande perigo neste momento: a destruição, a guerra, o ódio entre nós. Se nós fiéis não formos capazes de nos dar as mãos, abraçar-nos, beijar-nos e também rezar, a nossa fé será vencida. Esse Documento nasce da fé em Deus que é Pai de todos e Pai da paz. Condena toda destruição, todo terrorismo, desde o primeiro terrorismo da história que é o de Caim. É um documento que se desenvolveu em quase um ano, com ida e volta, orações. Ficou para amadurecer, um pouco confidencial, para não dar à luz a criança antes do tempo. Para que seja maduro" (Tornielli, 2019, online). 
al-tayyeb (2019), relacionando-a com a contribuição oferecida pela carta encíclica "Fratelli Tutti"“6 (2020) e destacando a importância, para a política internacional, da viagem do Papa Francisco ao Iraque (2021)7.

\section{1 de setembro de 2001}

Rubens A. Barbosa considera o binômio "Império" e novos "bárbaros", que nos ajuda a localizar melhor o contexto dos atentados do 11 de setembro de 2001 dentro dos condicionantes históricos-sociais-políticos-econômicos e, além disso, revela o que representam os próprios Estados Unidos, naquele momento, para o processo de globalização e para a própria ordem mundial. A afirmação de Barbosa de que os Estados Unidos já haviam superado os obstáculos da Guerra Fria há 10 anos do boom econômico - e, portanto, tinham atingido maturidade plena do seu poderio, além de ser enquanto potência mundial comparável à Roma imperial -, ajuda a entender o que era o "Império" no início deste século. Diz Barbosa (2002, p. 73):

Michael Hardt e Antonio Negri, ao descrever a natureza e o alcance do poder dos EUA na atualidade, apontam para a natural (e quase automática) identificação desse país como a autoridade definitiva a reger o processo de globalização e a própria ordem mundial. Segundo os autores, o exercício de poder dos EUA se dá no contexto do que denominam o 'Império', conceito definido com a nova forma global de economia, que não deve ser confundido com a desgastada noção de imperialismo. O Império não dispõe de um contorno territorial definido, na medida em que constitui, ele mesmo, um processo de 'desterritorialização', que incorpora gradualmente o mundo inteiro dentro de suas fronteiras abertas. O poder exercido pelo Império não tem limites e representa um regime que, efetivamente, abrange a totalidade do espaço. O Império governa todo o mundo 'civilizado' (conceito que, neste contexto, tende a confundir-se com 'globalizado'), não como regime histórico nascido da conquista, mas como uma ordem que, na realidade, suspende a história, determinando, dessa forma, o estado de coisas existentes.

Barbosa ainda cita Joseph Nye, renomado cientista político, e afirma: "Os EUA - 'país mais poderoso desde Roma', segundo Joseph Nye -, a única superpotência da atualidade, ocupam posição central nessa nova ordem capitalista 'imperial'" (Barbosa, 2002, p. 73). Assim, é possível considerar que os Estados Unidos são os "ordenadores" e os "regentes" do Império. Diz Barbosa: "Natural, nesse contexto, que os EUA, império dentro do 'Império', tenham logrado alçar-se, nos últimos anos, a uma situação de incontrastável superioridade em todos os campos do poder: econômico, tecnológico e militar" (Barbosa, 2002, p. 73) .

\footnotetext{
${ }^{6}$ No dia 3 de outubro de 2020, o Papa Francisco lançou sua carta encíclica "Fratelli Tutti": sobre a fraternidade e a amizade social. Inspirado no programa espiritual de São Francisco de Assis que propunha uma fraternidade aberta e simples irá sugerir que somente na cultura do encontro e do diálogo seja possível viver a fraternidade e a amizade social. Na carta encíclica, reconhece que estamos às sombras de um mundo fechado, e "entre a indiferença egoísta e o protesto violento, há uma opção sempre possível: o diálogo" (Francisco, 2020a, n.199). Em sua proposta sobre o modo como dialogar, propõe que acolhamos o dom do Espírito da amabilidade (chrestotes) que destrói a crueldade através de palavras doces que confortam, sustentam e tornam leve o caminhar. Diz: "Dizer palavras de incentivo, que confortam, consolam, fortalecem e estimulam" em vez de "palavras que humilham, angustiam, irritam, desprezam" (Francisco, 2020a, n. 223). Segundo o Papa: "A amabilidade (amorosidade) é uma libertação da crueldade que às vezes penetra nas relações humanas, da ansiedade que não nos deixa pensar nos outros, da urgência distraída que os outros também têm direito de ser felizes" (Francisco, 2020a, n. 224).

7 O Papa Francisco fez sua viagem apostólica ao Iraque de 5 a 8 de março de 2021.

8 É interessante reconhecer que para Barbosa o poderio político dos Estados Unidos "nada mais é do que o exercício dessa superioridade no campo da relação entre os Estados, decorre direta e naturalmente dessa situação, que os EUA procurarão manter por todos os meios. [...] Do ponto de vista econômico e financeiro, a hegemonia dos EUA revela-se claramente no diferencial de poder entre os principais atores globais: Os EUA representam cerca de $31,0 \%$ do produto interno bruto mundial (mais do que os quatro seguintes - Japão, Alemanha, Inglaterra e França -, juntos), são os maiores importadores e exportadores do planeta (17,0\% das importações mundiais de bens e $8 \%$ das de serviço; $13,0 \%$ das exportações mundiais de bens e $18,0 \%$ das de serviços, em dados de 1998), os maiores investidores e também os maiores recipientes de investimentos diretos, de longe, o principal e produtor e exportador de filmes e de programas de televisão no mundo. Por dez anos (1991-2000), a economia norte-americana cresceu em média 3,0\% (no mesmo período, a taxa média de crescimento do PIB japonês foi cerca de 1,5\% e o da União Européia de menos de 2,0\%)" (Barbosa, 2002, p. 73).
} 
O autor chega a considerar que a razão pela qual os Estados Unidos tornaram-se o "Império" deu-se pela "nova revolução industrial", genuinamente americana, que através dos avanços tecnológicos alcançados nas áreas da comunicação e do conhecimento, gerou transformações sem paralelo na operação das empresas americanas e que culminaram na "nova economia". Diz Barbosa (2002, p. 14, grifo do autor):

A superioridade tecnológica e militar dos EUA é igualmente evidente e revela-se num simples fato: os EUA são o único autor global da humanidade que consegue projetar poder militar simultaneamente em diferentes terrenos estratégicos em pontos distantes de seu próprio território (o orçamento de defesa dos EUA é superior à soma dos orçamentos militares dos seguintes 15 aliados ou competidores estratégicos, a começar pela Rússia, China e os principais países da OTAN). O contraste entre o know-how superior dos EUA em 'levar a guerra' ao resto do mundo e o poder militar apenas relativo dos demais competidores estratégicos, deve-se, além do peso específico do primeiro no campo econômico e tecnológico, à aplicação dos mesmos modelos organizacionais e produtivos que já tinham determinado a preeminência de seu tipo de capitalismo no final do século XIX e início do século XX. Na origem da defasagem de poder de fogo entre os EUA e o resto do mundo encontrar-se-ia, portanto, não apenas a simples capacitação tecnológica - que poderia ser eventualmente suprida no caso dos europeus ou mesmo no caso das duas grandes economias em transição para o capitalismo - mas uma organização superior de administração militar, que consegue aproveitar ao máximo os ganhos de produtividade revelados em um longo ciclo de crescimento econômico baseado nas virtudes inovadoras da 'nova economia' (informação, comunicações, processamento digital de insumos aplicados a novos tipos de armas).

O ocorrido no 11 de setembro de 2001 "vai buscar suas origens no outro lado do fenômeno analisado por Hardt e Negri: o território dos excluídos do Império - 'os bárbaros' (ou 'novos bárbaros', na opinião de Jan Christophe Ruffin)" (Barbosa, 2002, p. 75). As motivações remetem à essência do fenômeno terrorista e às suas consequências. Como afirma Barbosa (2002, p. 75):

As motivações por trás dos ataques remetem, de uma maneira ou de outra, à essência do fenômeno terrorista e as suas consequências : a exclusão de boa parte do mundo da prosperidade do Império (e a instabilidade política, a privação econômica e social dela decorrentes); a resistência a integrar-se à globalização (o choque 'civilizacional', as bases do fundamentalismo islâmico que rejeitam aspectos importantes dessa globalização); a arrogância imperial (o exercício do poder americano, a política externa dos EUA para o Oriente Médio, a Aliança com Israel, a 'ocupação' da Arábia Saudita.

O ataque ao poderio dos EUA simbolizado pelo World Trade Center e o Pentágono não ficou sem reação. Segundo Barbosa, houve "uma resposta feita ao mesmo tempo de unilateralismo, de intervencionismo e do eventual e bem medido ('à la carte') apelo ao multilateralismo e à cooperação seletiva, sob forma de alianças e parcerias" (Barbosa, 2002, p. 75) ${ }^{9}$.

Considerando este contexto do 11 de setembro de 2001, interessa-nos refletir também sobre a cultura. A própria religião, ou, melhor dizendo, religiões, enquanto sistema cultural, ajuda-nos a

\footnotetext{
9 Diz ainda Barbosa (2002, p. 75): "Contrariamente a conflitos anteriores (Guerra do Golfo, por exemplo), em que os EUA buscaram legitimar sua ação intervencionista através de alianças estratégicas com outros países ou entidades multilaterais, o 11 de setembro, ataque direto à própria essência do 'ser' americano, trouxe na percepção que constituía uma luta entre o bem e o mal, elementos que legitimavam uma reação imediata e unilateral. A rede de apoio e solidariedade que rapidamente se construiu em torno dos EUA não foi, nesse sentido, propriamente reivindicada por aquele país, mas sim esperada como fato natural. As declarações do Presidente Bush a esse respeito (quem não estiver com os EUA estarão contra) são a melhor tradução dessa expectativa: em um embate como o que se delineava, os países que não se encontravam sob o império do bem só poderiam estar do lado do mal. Nesse sentido, a construção de alianças pelos EUA para responder ao 11 de setembro corresponde mais a um ato de 'corroboração' de seu sistema de valores, do qual esperavam que os demais membros do 'Império' comungassem, do que propriamente à preocupação de legitimar ou apoiar ações contra seus atacantes (que também existiu, é bem verdade, no caso de países como o Paquistão ou a Índia, situados à margem do 'Império')" .
} 
compreender quão emblemático tornou-se este acontecimento que está na memória não apenas das famílias que até hoje choram seus entes queridos falecidos, mas também, das famílias do Oriente Médio e de tantas outras em tantas partes do globo que experimentaram e experimentam a violência imperial norte-americana, inclusive, na própria América.

Em relação ao 11 de setembro de 2001, como diz a jornalista islâmica Manji (2004); "quando os problemas dos outros não são reconhecidos por nós temos estes conflitos". Para a jornnalista, faz-se necessário que tenhamos uma visão multicultural para sermos capazes de compreender e conviver em meio a diversidade (Manji, 2004). E, justamente, é esta a reflexão que fazem Jurgen Habermas e Joseph Ratzinger a respeito da questão sobre o que mantém o mundo unido. No debate "Dialética da secularização", ambos refletem sobre o desafio que se coloca para as sociedades no globo. Em particular, Joseph Ratzinger pensa a problemática da interculturalidade no que diz respeito ao reconhecimento de que a fé cristã e a racionalidade, ainda que deem "o sentido do mundo", não são as únicas grandes culturas do globo e, por isso, faz-se necessário pensar sobre a convivência plural neste século.

\section{Fé cristã, racionalidade e "o sentido do mu ndo" a pós o 11 de setembro}

Jurgen Habermas reconhece que a religião precisa encontrar plausibilidade junto à sociedade e ela torna-se credível quando na sua atuação perante o mundo aproxima-se da racionalidade própria da modernidade. Em outras palavras, quando a religião realiza seu processo de secularização, ela coloca-se em atitude de maior comprometimento com as pautas próprias do Estado de Direito. Habermas aponta a necessidade de uma reflexão sobre o modus vivendi no qual o Estado liberal reconheça a necessidade de garantir a integração política de seus cidadãos (sejam eles religiosos ou seculares) ${ }^{10}$.

A reflexão sobre a secularização foi feita por Max Weber no século XIX. Ele compreende que neste processo, também chamado de "desencantamento do mundo", as religiões perdem o poder central que detinham, isto é, o destino das pessoas não mais está nas mãos de Deus, representados pelos seus líderes religiosos, mas o próprio ser humano decide sobre si e consequentemente pela história (Hock, 2010)

O "desencantamento do mundo" leva a um processo de racionalização do mundo e, para Weber, é no judaísmo que se reconhece este movimento de "desencanto". A fé hebraica num único Deus, o monoteísmo, considera a crença aos outros deuses como idolatria, e apresenta-se como uma religião eticista, firmada na aliança. Observa Max Weber que o mesmo ocorreu com a sociedade moderna emergente naquela época. Entretanto, a ciência realiza o "desencantamento" não só com a magia, mas também com a religião.

\footnotetext{
10 Diz Habermas e Ratzinger (2007, p. 53, grifo do autor): "De um lado, a consciência religiosa se viu coagida a aceitar processos de adaptação. Toda religião é originariamente uma 'visão do mundo' ou uma 'comprehensive doctrine', inclusive no sentido de reivindicar a autoridade de estruturar a forma de vida como um todo. Sob a pressão da secularização do conhecimento, da neutralização do poder do Estado e da liberdade religiosa generalizada, a religião se viu obrigada a desistir dessa pretensão ao monopólio de interpretação e à forma normativa e abrangente de vida. Com a diferenciação funcional progressiva de sistemas sociais parciais, a vida da comunidade religiosa também se separa de seu entorno social. O papel do membro da comunidade se diferencia do papel do cidadão. Como o Estado liberal depende da integração política de seus cidadãos e como essa integração não pode ficar restrita a um mero modus vivendi, essa diferenciação das condições do membro não pode esgotar-se numa simples adaptação cognitiva do etos religioso às leis impostas pela sociedade secular. Antes é necessário que a ordem jurídica universalista e a moral igualitária da sociedade sejam de tal maneira conectadas internamente ao etos da comunidade e que um elemento decorra consistentemente do outro. Para este tipo de "inserção", John Rawls escolheu a imagem do módulo: esse módulo da justiça secular deve encaixar-se nos respectivos nexos legitimadores ortodoxos, apesar de ter sido construído à base de razões ideológicas neutras".
} 
Segundo Weber, o racionalismo é uma característica particular do desenvolvimento cultural do Ocidente, mas já pressupõe um processo designado por Weber como 'desencantamento' ('desenfeitização') e considerado um fenômeno histórico-religioso: por assim dizer, o desencantamento é inerente à história da religião e representa uma reação à experiência da "irracionalidade" do mundo. As religiões tentaram dar uma resposta a essa irracionalidade, mas depois foram suplantadas, passo a passo, por novas tentativas de interpretação, quando a experiência recorrente da ausência de sentido e da inexplicabilidade exigia novas respostas. O desenvolvimento chegou, a partir de religiões naturais e passando por religiões cúlticas e religiões éticas, ao ponto que a ética religiosa estava confrontada com o problema do sofrimento injusto. Essa questão, também chamada de 'problema da teodicéia', juntamente com a contínua experiência da 'irracionalidade', levou a uma desvalorização do mundo, já que uma atribuição de sentido uniforme não parecia mais possível. Na contrarreação e com a emancipação do capitalismo de sua história inicial religiosa, abriu-se o caminho para uma 'racionalização' de amplas áreas da vida. Essas áreas obedecem agora a leis próprias que são totalmente autônomas em relação a normas ou interpretações religiosas (Hock, 2010, p. 110).

A secularização é a afirmação positivista de que a religião e mesmo a filosofia são estágios inferiores à própria ciência que é entendida como grande ideal humanitário a ser almejado, a ponto de Augusto Comte falar de uma "religião de humanidade"11. Com o surgimento do Estado, as religiões passam a ser consideradas instituições civis da sociedade, cuja autonomia depende da garantia dada pelo Direito.

De fato, a religião, em particular o Cristianismo, perante a modernidade, precisou rever sua relação com a própria História junto ao processo de secularização. Semelhante ao judaísmo, o Cristianismo também fez sua racionalização do mundo, entretanto, além de realizar seu encontro cultural com o hebraísmo, também o fez junto à cultura helênica e, portanto, também pode ser considerado filosoficamente enquanto produziu uma religião eticista.

Joseph Ratzinger reconhece que o encontro com o helenismo fez com que o Cristianismo vivesse um profundo iluminismo e, consequentemente, fizesse uma racionalização do mundo, pois, por meio da reflexão filosófica como fundamento da teologia, permitiu uma nova concepção do Logos. O período da Patrística e, mais ainda, a própria Escolástica conheceram a riqueza destes encontros culturais.

Para Ratzinger, há uma contradição no processo de secularização feito pela modernidade, ao negar ao Cristianismo seu espectro moderno. Na genealogia da modernidade, a fé cristã é constituinte, pois sua contribuição é justamente relembrar à razão que ela não é só "ratio", mas "intelectos". Ao solicitar o alargamento da razão e, consequentemente, o retorno da metafísica à filosofia, propõe que seja repensada a modernidade que, segundo ele, não se pode compreender sem a fé cristã. Assim explica Rudy Albino da Assunção acerca da teologia ratzingeriana:

\footnotetext{
11 Augusto Comte (1798-1857) é considerado o iniciador do pensamento sociológico, tendo cunhado o termo "sociologia". Para Comte, a sociologia deveria tornar-se uma "ciência positiva". O positivismo sustenta que a ciência deve se preocupar apenas com entidades observáveis que sejam conhecidas pela experiência direta. Uma abordagem positivista à sociologia visa a produção de conhecimento sobre a sociedade, com base em evidências empíricas obtidas com observação, comparação e experimentação. A lei dos três estágios de Comte assinala que as tentativas humanas de entender o mundo passam por estágios teológicos, metafísicos e positivos. No estágio teológico, o pensamento era guiado por ideias religiosas e pela crença de que a sociedade era expressão da vontade divina. No estágio metafísico, que tomou frente por volta da época da Renascença, a sociedade passou a ser vista em termos naturais, e não sobrenaturais. O estágio positivo, anunciado pelas descobertas e realizações de Copérnico, Galileu e Newton, estimulou a aplicação de técnicas científicas ao mundo social. De acordo com essa visão, Comte considerava a sociologia como a última ciência a se desenvolver - com base na física, na química e na biologia -, mas também como a mais significativa e complexa de todas as ciências. No final da sua carreira, Comte criou planos ambiciosos para a reconstrução da sociedade francesa em particular e para as sociedades humanas em geral, com base em seu ponto de vista sociológico. Ele clamava pelo estabelecimento de uma "religião de humanidade" que abandonaria a fé e o dogma, em favor de um embasamento científico (Giddens, 2012)
} 
A noção de Logos é fundamental na teologia ratzingeriana e aí coloca-se o fundamento do diálogo (relação) entre fé e razão: o Deus bíblico, ou melhor, como o Novo Testamento o descreve, é Logos, é Razão Criadora e que se comunica. O Deus que é Logos comunica-se, dialoga com a humanidade por meio do rosto de Jesus. Esta afirmação oferece condições para um renovado diálogo entre fé e razão que não implica um repensar o papel da fé cristã no debate da sociedade plural e secular, mas um resgate da filosofia (e, com ela, da metafísica, consequentemente): para ele, 'a crise da modernidade não é sinônimo de declínio da filosofia', mas cabe particularmente a esta última compreender a natureza desta crise, pois a modernidade bem compreendida implica uma 'questão antropológica'; a modernidade não é um simples fenômeno cultural, historicamente datado; ela na realidade obriga a uma nova projectualidade, a uma compreensão mais exata da natureza do homem. Assim, o alargamento da razão seria uma nova abertura à realidade à qual a pessoa está chamada na sua unitotalidade, superando antigos preconceitos e reducionismos, para se abrir também assim o caminho para uma verdadeira compreensão da modernidade (Assunção, 2018, p.170, grifo do autor).

A história compreendida a partir de Vico e depois na ótica marxista promove um reducionismo, pois considera o ser humano a partir da ação. A existência é reduzida ao "faciendum". O ser humano compreende-se a partir do que faz ou fabrica. Atualmente, essa concepção impõe-se sobre o globo a partir de um "pensamento único"12 expresso por uma ideologia libertária e tecnocrática.

Em relação à questão do que mantém o mundo unido, Ratzinger afirma o valor do Estado e reconhece que cabe ao Direito colocar limites ao poder ilimitado que alcançou o ser humano. É fundamental fazer a pergunta sobre quem coloca limites ao poder, pois a própria comunidade internacional não teria forças para interromper, por exemplo, uma guerra nuclear, caso ela ocorresse.

$\mathrm{E}$, considerando tais riscos, recuperar o direito natural que é anterior ao direito positivo pode favorecer uma consciência religiosa de fraternidade. O direito natural - o sentido da essencialidade humana, enquanto pessoa que possui uma dignidade humana inviolável e inalienável a ser respeitada -, funda a igualdade fundamental, na perspectiva de Joseph Ratzinger.

Entretanto, ele reconhece que não se pode negar o desafio da convivência plural como o empenho a ser feito neste século. Ele afirma que, mesmo que reconheçamos que a fé cristã e a racionalidade são as duas grandes culturas do ocidente e que oferecem "o sentido do mundo", não se pode negar a emergência da cultura asiática e islâmica e que, portanto, a pretensa universalidade de ambas acaba por ser apenas uma abstração. Diante dessa afirmação, é preciso reconhecer que não se trata de não considerar o diálogo como caminho possível para uma convivência melhor, mas uma tomada de consciência da realidade de interculturalidade que o próprio pluralismo expressa. Diz Habermas e Ratzinger (2007, p. 83):

O espaço cultural islâmico traz a marca de tensões semelhantes: um leque amplo se estende desde o absolutismo fanático de figuras como Bin Laden até as atitudes abertas a uma racionalidade tolerante. O terceiro grande espaço cultural, a cultura indiana, ou, melhor dizendo, os espaços

\footnotetext{
12 Bartolomeo Sorge (2018, p. 47), ao comentar sobre a "ideologia tecnocrática" de Bento XVI na carta encíclica Caritas in Veritate, afirma que "o vazio deixado pelas ideologias clássicas foi ocupado por uma nova ideologia 'libertária' e 'tecnocrática', que se tornou uma espécie de 'pensamento único' dominante. Esta nova 'ideologia tecnocrática' (como Bento XVI a chama) alimenta o individualismo e o egoísmo dos nossos dias e se opõe radicalmente ao próprio conceito de 'bem comum'. De fato, a ideologia tecnocrática subestima o fato de que a sociedade humana é uma comunidade de pessoas, ou seja, de seres-em-relação entre eles, e a considera antes um rebanho de indivíduos anônimos um ao lado do outro, cada um dos quais pensa antes de tudo em si mesmo. Por conseguinte, o juízo ético permanece subordinado à eficiência, à inovação tecnológica e ao consenso social, sem qualquer referência aos valores radicados na pessoa humana, na sua consciência moral e religiosa".
} 
culturais do hinduísmo e do budismo, apresenta as marcas de tensões semelhantes, mesmo que estas, à primeira vista, mostrem-se menos dramáticas. Essas culturas também se veem confrontadas tanto com as pretensões do racionalismo ocidental quanto com os apelos da fé cristã, ambos presentes em seu meio. Elas assimilam uma e outra de formas diferentes, tentando salvar, ao mesmo tempo, sua própria identidade. As culturas tribais da África e da América Latina, estas últimas reavivadas por certas teologias cristãs, completam o quadro. Em grande parte, essas culturas questionam não só a racionalidade ocidental, mas também a pretensa universalidade cristã. [...] Fato é que nossa racionalidade secular, por mais que ela pareça evidente a nossa mente de formação ocidental, não o é para qualquer mente. Em sua tentativa de ser evidente, essa racionalidade esbarra em limites. Sua evidência está ligada, de fato, a determinados contextos culturais, o que a obriga a reconhecer que, como tal, ela não é transparente para toda a humanidade, de modo que não pode ser operacional no todo.

Robert Bellah havia observado uma orientalização do ocidente com o movimento de "contracultura" na década de 60. Ele afirma que nesse contexto é possível observar um fenômeno de nova consciência religiosa que foi chamado de "New Age". Houve uma decepção juvenil com o movimento do avivamento bíblico, pois as posturas rigoristas dos pais, e mesmo a opção dos Estados Unidos por um reducionismo antropológico compreendido no utilitarismo pragmático, levaram os jovens a um movimento de almejar "liberdades". O Woodstock é considerado um evento que se tornou símbolo desta mudança. Grupos de jovens orientados com filosofias asiáticas nasceram por toda a América. Bellah afirma que este movimento revela o quanto a religião no ocidente havia se esvaziado espiritualmente e se tornado apenas uma consequência do status quo vinculado a uma vida pragmática (Bellah, 1986).

É neste tempo que surgem os "hippies" com propostas alternativas a uma vida de empregos fúteis. Ainda, diz Bellah, este movimento de renovação cultural alcançou o próprio Cristianismo. Com Martin Luther King, seu discurso contra a segregação racial motivando atitudes de desobediência civil e com o imperativo categórico do amor, uma nova concepção de Cristianismo para a América foi favorecida, ainda que fortemente enraizada no movimento de avivamento bíblico das igrejas históricas tradicionais. Em relação ao catolicismo, o Concílio Ecumênico Vaticano II foi um acontecimento de renovação cultural da Igreja e, consequentemente, de sua relação com o mundo (Bellah, 1986).

Ainda que seja possível observar a nova consciência religiosa da "New Age" nos grupos denominados NMR (Novos Movimentos Religiosos) ${ }^{13}$, é importante entender que ela não se restringe somente a esses grupos religiosos. Muitas vezes, ela está disseminada em outros espaços, como em aulas de yoga, em uma sessão de exercícios de academia, ou ainda com o johrei como parte do método de relaxamento de uma sessão de terapia.

Isto nos leva a considerar o quanto a cultura asiática é uma segunda grande cultura que influencia "o sentido do mundo", cuja hegemonia era da fé cristã e da racionalidade. Mas, também é preciso considerar a cultura islâmica que tem crescido em todo o globo, em particular, no ocidente; em especial, na Europa. A França é o país europeu mais islâmico. Os desafios da convivência plural fazem-se sentir desde a escolha por uso de vestimentas oriundas da cultura árabe.

\footnotetext{
13 De acordo com Guerriero (2006, p. 44): "[...] são extremamente diversos. Qualquer tentativa de classificação será sempre limitada. Em um olhar mais apressado, aparentemente temos clareza do que se trata. Praticamente todos nós já sabemos o que é um NMR. Porém, quanto mais focamos nosso olhar e tentamos mergulhar para baixo da linha da superfície, mais nossos olhos ficam turvos. O fenômeno insiste em ser cada vez mais complexo, confundindo-nos ainda mais. Saímos da experiência com a sensação de incompreensão. Mas isso não satisfaz a Ciência da Religião. É preciso procurar alguns contornos, algumas regularidades e tendências. Só dessa maneira estaremos não apenas atuando de acordo com os métodos científicos, mas contribuindo para elucidar melhor o que anda acontecendo em termos religiosos em nossa sociedade".
} 
Segundo o filósofo polonês Bauman, a França projeta-se como uma cidade aberta desde a Revolução, entretanto, diante de um histórico de guerras e conflitos étnicos, tende a um isolamento maior, pois considera o estrangeiro como ameaça. Para ele, a França e outros países europeus promovem uma política de "securitização". Diz Bauman (2017, p. 38, grifo do autor):

[...] A política de 'securitização' ajuda a reprimir antecipadamente nossas dores de consciência - como observadores da visão de seus atormentados alvos. Ela leva à 'adiaforização' do tema dos migrantes (ou seja, excluindo-os, bem como aquilo que lhes é feito, da avaliação moral). Uma vez classificados pela opinião pública na categoria de potenciais terroristas, os migrantes se encontram além dos domínios e fora dos limites da responsabilidade moral - e, acima de tudo, fora do espaço da compaixão e do impulso de ajudar. Com efeito, se treinadas de acordo com o princípio de 'securitização', muitas pessoas sentem-se - de modo consciente ou não - satisfeitas por se livrar da responsabilidade pelo destino dos miseráveis, assim como das pressões de um dever moral que, de outra forma, iria inevitavelmente aparecer para atormentar as testemunhas. Por esse alívio - de modo consciente ou não -, muitas pessoas são gratas. A quem? Obviamente, aos políticos que tensionam músculos e falam duro. Como observou no Guardian Christopher Catrambone: Depois dos atentados terroristas em Paris e do alarmismo subsequente, mais uma vez começamos a colocar pessoas em risco. A tragédia humana de gente fugindo pelo mar para escapar ao terrorismo está sendo depreciada por acusações amargas, pela construção de muros e pelo medo de que esses refugiados venham nos matar. A maioria só está fugindo da guerra no Oriente Médio. Mas, mesmo enredados entre o ódio europeu e a violência que os fez sair de seus países, os refugiados ainda se aventuram pelos mares da degradação.

A islamofobia não é uma realidade apenas europeia. Em todo o globo, em particular no Ocidente, têm crescido expressões xenófobas ao Islã. Para Juan José Tamayo, a teologia tem um papel preponderante neste esforço para superar os estereótipos e toda forma de preconceito religioso contra o Islamismo. Ele sugere uma teologia islã-cristã feminista como possibilidade de um diálogo inter-religioso e intercultural sincero que favoreça o estreitamento dos laços de fraternidade para poder chamar ao muçulmano de "hermano islam" (Tamayo, 2019).

Se a teologia tem um papel preponderante, então, as religiões também podem favorecer este diálogo inter-religioso e intercultural. É o que observamos no esforço que tem feito o Catolicismo com o Islamismo em buscar uma aproximação, que é religiosa, mas, de fato, representa um caminho de interculturalidade junto ao islamismo e, com isto, oferece novos elementos para uma compreensão do que seja "o sentido do mundo" hoje. O encontro do Papa Francisco com o Grande Imã Ahmad al-tayyeb pode ser considerado um ato simbólico enquanto sinaliza a aproximação entre ocidente e oriente, fé cristã, racionalidade e islamismo. A declaração conjunta católico-islâmico por uma cultura do diálogo expressa um compromisso que é religioso, mas também político, e podemos dimensionar a força deste instrumento através do significado que tem a viagem do Papa Francisco ao Iraque neste atual contexto de pandemia global da Covid-19.

\section{Da cultura do encontro àculturadodiálogo}

Em 2019, o Papa Francisco visitou o Grande Imã Ahmad al-tayyeb e, neste encontro, foi assinada a declaração conjunta católico-islâmico por uma cultura do diálogo, em que, ambos afirmam que são contrários ao terrorismo promovido pelas religiões e que devem empenhar-se no crescimento do diálogo 
inter-religioso e intercultural ${ }^{14}$. Além disso, o documento traz considerações importantes acerca da concepção de Deus: afirma que Deus não precisa de ninguém para defendê-lo e que não se pode aceitar que o Seu nome seja usado para aterrorizar. Ambos se comprometem em empenhar suas religiões na promoção de uma cultura do diálogo. Lemos no documento:

Em nome de Deus e de tudo isto, Al-Azhar al-Sharif - com os muçulmanos do Oriente e do Ocidente - juntamente com a Igreja Católica - com os católicos do Oriente e do Ocidente - declaramos adotar a cultura do diálogo como caminho; a colaboração comum como conduta; o conhecimento mútuo como método e critério. Nós - crentes em Deus, no encontro final com Ele e no Seu Julgamento -, a partir da nossa responsabilidade religiosa e moral e através deste Documento, rogamos a nós mesmos e aos líderes do mundo inteiro, aos artífices da política internacional e da economia mundial, para se comprometer seriamente na difusão da tolerância, da convivência e da paz; para intervir, o mais breve possível, a fim de se impedir o derramamento de sangue inocente e acabar com as guerras, os conflitos, a degradação ambiental e o declínio cultural e moral que o mundo vive atualmente. Dirigimo-nos aos intelectuais, aos filósofos, aos homens de religião, aos artistas, aos operadores dos mass-media e aos homens de cultura em todo o mundo, para que redescubram os valores da paz, da justiça, do bem, da beleza, da fraternidade humana e da convivência comum, para confirmar a importância destes valores como âncora de salvação para todos e procurar difundi-los por toda a parte (Francisco; Al-Tayyeb, 2019, online, grifo do autor).

Na carta encíclica "Fratelli Tutti" de 3 de outubro de 2020, o Papa Francisco propõe uma cultura do diálogo que favoreça a amizade social que possa ser vivida como fraternidade. Para isto, ele sugere o programa espiritual de São Francisco de Assis - Fratelli Tutti -, como inspiração para a experiência de uma fraternidade simples e aberta. No texto, o Papa recorda o evento intitulado "A hospedagem" que vivenciou São Francisco de Assis quando estava a caminho de Jerusalém. Ele pede acolhimento para o Sultão Malik e este se surpreende com o gesto de Francisco. Segundo a narrativa, neste período, estavam ocorrendo as cruzadas, e cristãos e mouros eram inimigos. A surpresa do Sultão era justamente saber que aquele homem maltrapilho à sua frente era um cristão e não queria fazer-lhe mal, e sim, ser por ele hospedado.

A partir da narração deste episódio, o Papa Francisco procura apresentar uma reflexão que considere o exercício da fraternidade. Por meio da encíclica, oferece uma leitura sobre os tempos atuais, enfatizando a necessidade do diálogo e da amizade social. Diz o Papa: "Entre a indiferença egoísta e o protesto violento, o diálogo é sempre um caminho possível" (Francisco, 2020a, n. 199). Propõe ainda a amabilidade (chrestotes) que é um fruto do Espírito - segundo ensina a teologia paulina -, e que destrói

\footnotetext{
${ }^{14}$ A viagem do Papa Francisco a Adu Dhabi, nos Emirados Árabes Unidos, segundo Marco Impagliazzo, presidente da Comunidade Sant'Egídio, "foi caracterizada por dois abraços e duas assinaturas. O abraço de paz com o Grão-Imã de Al Azhar, e, portanto, com o mundo muçulmano sunita, que sela um caminho de encontros do qual sou testemunha com a Comunidade de Sant'Egídio no 'Espírito de Assis'. É um abraço que levou à primeira das duas assinaturas, aquela em um documento conjunto entre a Igreja Católica e Universidade de Al-Azhar (o mais importante ponto cultural e religioso do islamismo sunita) sobre a fraternidade humana pela paz mundial e a convivência comum. Nós nos declaramos irmãos com todas as implicações positivas que este nome traz em si. Como testemunhas ao abraço e à assinatura, estavam os líderes das grandes religiões mundiais e, humildemente, a Comunidade. É a realização do sonho de São João Paulo II: as religiões rezam pela paz e umas pelas outras. Não mais uns contra os outros. Assim, disse o Papa em seu discurso: 'Cabe às religiões neste momento delicado histórico, uma tarefa que não se pode adiar mais: contribuir ativamente para desmilitarizar o coração do homem. A corrida aos armamentos, o alargamento das respectivas zonas de influência, as políticas agressivas em detrimento dos outros nunca trarão estabilidade. A guerra nada mais pode criar senão miséria; as armas nada mais, senão morte. A fraternidade humana impõe-nos, a nós representantes das religiões, o dever de banir toda a nuance de aprovação da palavra guerra. Restituamo-la à sua miserável crueza'. A segunda assinatura foi colocada pelo Papa, ao lado de Al Tayyeb e os dois governantes dos Emirados, na primeira pedra de uma nova igreja dedicada a São Francisco, um dom dos Emirados para o papa e os católicos que vivem aqui. É para eles o segundo abraço dessa jornada. Milhares e milhares de católicos, migrantes da Ásia e da África, que buscam um futuro nesta terra, também através da ajuda de suas famílias que muitas vezes permanecem em seus países de origem. Aqui também o papa abraçou uma periferia humana e existencial, feliz por poder receber a palavra e o abraço de um pai. O Oriente Médio não é uma terra de emigração de cristãos, mas também de imigração. O sonho é que essas pessoas encontrem aqui, além do acolhimento, uma via de integração. Desses abraços e dessas assinaturas sou testemunha feliz com toda a Comunidade de Sant'Egídio" (Impagliazzo, 2019, online).
} 
a crueldade, iniciando por "des-violentar" a linguagem em relação ao outro. Assim como sugere São Francisco de Assis como inspiração para se viver a fraternidade, encerra a carta indicando o Beato Charles de Foucauld para inspirar o sentido de ser o irmão universal na ótica da amizade social que descreve no texto.

Neste espaço de reflexão sobre a fraternidade universal, senti-me motivado especialmente por São Francisco de Assis e também por outros irmãos que não são católicos: Martin Luther King, Desmond Tutu, Mahatma Mohandas Gandhi e muitos outros. Mas quero terminar lembrando uma outra pessoa de profunda fé, que, a partir da sua intensa experiência de Deus, realizou um caminho de transformação até se sentir irmão de todos. Refiro-me ao Beato Carlos de Foucauld. O seu ideal duma entrega total a Deus encaminhou-o para uma identificação com os últimos, os mais abandonados no interior do deserto africano. Naquele contexto, afloravam os seus desejos de sentir todo o ser humano como um irmão, e pedia a um amigo: 'Peça a Deus que eu seja realmente o irmão de todos'. Enfim queria ser 'o irmão universal'. Mas somente identificando-se com os últimos é que chegou a ser irmão de todos. Que Deus inspire este ideal a cada um de nós. Amém (Francisco, 2020a, n. 286, 287).

A cultura do diálogo nasce da cultura do encontro e as razões que nos movem são a fraternidade e a amizade social. Para os cristãos, frisa o Papa Francisco, tal exigência fundamenta-se na essência do Evangelho que se compreende na máxima: Ama o teu próximo como a ti mesmo ${ }^{15}$. É na força do amor que as relações humanas são transformadas e a sociedade renovada. Essa exigência do amor tem no pontificado de Francisco o sentido de misericórdia ou mesmo ternura.

Antonio Spadaro afirma que ao analisar a política de Francisco reconhecemos que o tema da misericórdia perpassa seu discurso. A misericórdia aparece, no interior da Igreja, nas reformas que precisam ser feitas, sobretudo, no que tange ao acolhimento das pessoas em situação de sofrimento e excluídas de alguns acessos à participação sacramental. E, revela-se para fora, enquanto compreende uma cultura que exige compromisso com os pobres e excluídos. Segundo Antonio Spadaro, a misericórdia como política

\footnotetext{
${ }^{15}$ No capítulo VIII intitulado "As religiões ao serviço da fraternidade no mundo" da carta encíclica "Fratelli Tutti", o Papa Francisco diz a respeito da identidade cristã: "A Igreja valoriza a ação de Deus nas outras religiões e 'nada rejeita do que, nessas religiões, existe de verdadeiro e santo. Olha com sincero respeito esses modos de agir e viver, esses preceitos e doutrinas que [...] refletem não raramente um raio da verdade que ilumina todos os homens'. Todavia, como cristãos, não podemos esconder que, 'se a música do Evangelho parar de vibrar nas nossas entranhas, perderemos a alegria que brota da compaixão, a ternura que nasce da confiança, a capacidade da reconciliação que encontra a sua fonte no facto de nos sabermos sempre perdoados-enviados. Se a música do Evangelho cessar de repercutir nas nossas casas, nas nossas praças, nos postos de trabalho, na política e na economia, teremos extinguido a melodia que nos desafiava a lutar pela dignidade de todo 0 homem e mulher'. Outros bebem doutras fontes. Para nós, este manancial de dignidade humana e fraternidade está no Evangelho de Jesus Cristo. Dele brota, 'para o pensamento cristão e para a ação da Igreja, o primado reservado à relação, ao encontro com o mistério sagrado do outro, à comunhão universal com a humanidade inteira, como vocação de todos'. Chamada a encarnar-se em todas as situações e presente através dos séculos em todo o lugar da terra - isto mesmo significa 'católica' -, a Igreja pode, a partir da sua experiência de graça e pecado, compreender a beleza do convite ao amor universal. Com efeito, 'tudo o que é humano nos diz respeito [...]; onde quer que as assembleias dos povos se reúnam para determinar os direitos e os deveres do homem, sentimo-nos honrados, quando no-lhe permitem, tomando lugar nelas'. Para muitos cristãos, este caminho de fraternidade tem também uma Mãe, chamada Maria. Ela recebeu junto da Cruz esta maternidade universal $(J o$ 19, 26) e cuida não só de Jesus, mas também do «resto da sua descendência' (Ap 12, 17). Com o poder do Ressuscitado, Ela quer dar à luz um mundo novo, onde todos sejamos irmãos, onde haja lugar para cada descartado das nossas sociedades, onde resplandeçam a justiça e a paz. Como cristãos, pedimos que, nos países onde somos minoria, nos seja garantida a liberdade, tal como nós a favorecemos para aqueles que não são cristãos onde eles são minoria. Existe um direito humano fundamental que não deve ser esquecido no caminho da fraternidade e da paz: é a liberdade religiosa para os crentes de todas as religiões. Esta liberdade manifesta que podemos 'encontrar um bom acordo entre culturas e religiões diferentes; testemunha que as coisas que temos em comum são tantas e tão importantes que é possível individuar uma estrada de convivência serena, ordenada e pacífica, na aceitação das diferenças e na alegria de sermos irmãos porque filhos de um único Deus'. Ao mesmo tempo, pedimos a Deus que fortaleça a unidade dentro da Igreja, unidade que se enriquece com diferenças que se reconciliam pela ação do Espírito Santo. Com efeito, 'num só Espírito, fomos todos batizados para formar um só corpo' $(1$ Cor 12 , 13), onde cada um presta a sua contribuição peculiar. Como dizia Santo Agostinho, 'o ouvido vê através do olho, e o olho escuta através do ouvido'. Também é urgente continuar a dar testemunho dum caminho de encontro entre as várias confissões cristãs. Não podemos esquecer o desejo expresso por Jesus: 'Que todos sejam um só' (Jo 17, 21). Ao escutar o seu convite, reconhecemos com tristeza que, no processo de globalização, falta ainda a contribuição profética e espiritual da unidade entre todos os cristãos. Todavia, 'apesar de estarmos ainda a caminho para a plena comunhão, já temos o dever de oferecer um testemunho comum do amor de Deus por todas as pessoas, trabalhando em conjunto ao serviço da humanidade'" (Fransciso, 2020a, n. 277-280).
} 
internacional em Francisco inicia-se com sua acolhida aos refugiados. A partir desta postura, começa um processo de repensar as ações por outras lideranças, seja na Europa ou em outras partes do globo. Para Spadaro, na política de Francisco, há uma forte teologia radical que se funda na sua raiz essencial: a volta de Deus.

La misericordia politica di Bergoglio ha una forte radice teologica, evidentemente, e si fonda su una radice essenziale: il volto di Dio. In fondo, il Giubileo della Misericordia consiste in un nuovo annuncio di Dio ed esprime l'impegno a riaprire in termini non soltanto astratti, mas esistenziali, la questione di Dio, su chi è Dio. Dire che Dio è onnipotente ed eterno significa - come ci ha insegnato san Tommaso - che lo è nella sua misericordia. [...] Che cosa significa la misericordia como categoria politica? In estrema sintesi, possiamo dire: non considerare mai niente e nessuno come definitivamente 'perduto' nei rapporti tra nazioni, popoli e Stati. Questo è il nucleo del significato politico. Per questo ha scritto Francesco: 'È auspicabile che anche il linguaggio della politica e della diplomazia si lasci ispirare dalla misericordia, che nulla dà mai perduto'. La misericordia riorienta le acque del corso della storia e apre gli argini del determinismo. Questa apertura è ben resa simbolicamente dall'apertura di migliaia e migliaia di Porte Sante nel mondo (Spadaro, 2016, p. 212 , grifo do autor).

Entretanto, a misericórdia também se faz sentir na perspectiva apontada na carta encíclica "Laudato Si" (Francisco, 2015) que solicita ao leitor um despertar para uma consciência dolorosa (empática) que não seja indiferente ao sofrimento da terra e dos pobres. Tal perspectiva concretiza-se enquanto decisão por meio do Sínodo da Amazônia ${ }^{16}$. Atualmente, o tema da misericórdia pode ser considerado catalisador de outros temas que emergem na linguagem oferecida pelo Papa Francisco: ternura, proximidade, cultura do encontro, cultura do diálogo, etc.

Bartolomeo Sorge explica que as críticas ao Papa Francisco no que diz respeito a ser herege ou cometer heresias não encontram fundamento teológico e nem eclesial, mas trata-se de uma perspectiva de ótica. Enquanto, para alguns grupos, Deus é compreendido como juiz legislador e suas experiências religiosas são pautadas por um rigorismo, a ótica do Papa Francisco é a do Deus misericordioso, o Pai de Jesus que ele revelou com o seu rosto. Diz Sorge (2018, p. 111):

Quem critica o papa se coloca na ótica típica do homem que olha a grandeza de Deus criador (juiz e legislador, exigente e severo), como acontecia sobretudo no Antigo Testamento. O papa Francisco, ao contrário, se coloca na ótica de Deus, Pai, infinitamente bom e misericordioso, que olha com amor o homem e a sua fragilidade, como se revelou em Jesus no Evangelho.

Antonio Spadaro ainda afirma que a concepção de Deus de Francisco tem seu fundamento no Evangelho da Misericórdia e, portanto, procura por meio de suas viagens, sobretudo, ir comunicando a concepção de Deus como integração. Deus é integração e, portanto, não é separação, exclusão e totalitarismo. Com essa consideração, podemos afirmar que diante de um contexto de interculturalidade, estas ações político-religiosas corroboram com a possibilidade de ir se repensando a convivência que é plural e consequentemente oferecendo um novo "sentido de mundo" não mais hegemônico da fé cristã e da racionalidade apenas.

\footnotetext{
${ }^{16}$ Os sonhos do Papa Francisco para a Amazônia estão descritos nos capítulos da exortação apostólica pós-sinodal: "Querida Amazônia" (2020b). e diríamos, são os sonhos da Igreja para a Amazônia: um sonho social que desperte em nós o sentimento de injustiça e reconheçamos o crime que promovem contra a Amazônia, em particular aos povos indígenas, e por meio do perdão, no caminho da reconciliação proponha-se um diálogo social respeitando o sentido comunitário dos povos amazônicos. Um sonho cultural que seja capaz de reconhecer o poliedro amazônico, havendo o empenho por cuidar das raízes, a sabedoria ancestral das comunidades indígenas, e neste encontro intercultural, sejam defendidas suas culturas que são constantemente ameaçadas, colocando seus povos em risco. E o sonho ecológico feito de água, com o desejo de despertar para um amor maternal com a Amazônia, e assim compreender a dimensão do cuidado com ela. Ouvir o grito da Amazônia sem ser indiferente. Contemplar a terra sem males e mesmo buscar no bem viver dos povos da floresta recuperar a harmonia que o Evangelho da Criação anuncia.
} 
A viagem do Papa Francisco ao Iraque ocorrida de 5 a 8 de março foi uma celebração do empenho de dois países e duas religiões na cultura do encontro e do diálogo. Num país evidentemente islâmico, o Papa Francisco foi como chefe de estado e o líder de uma grande religião. E, neste sentido, sua ida ao Iraque é, do ponto de vista diplomático, uma viagem de "prevenção". O prevenir aqui diz respeito a significar tal viagem como um convite para o mundo abrir-se ao Iraque e, necessariamente, ao Islã.

Essa viagem foi considerada a mais importante de sua história. Em primeiro lugar, pelo aprofundamento do diálogo inter-religioso e desmascaramento da falácia de que os conflitos nacionais, e também internacionais - como é o caso de Israel contra a Palestina -, são religiosos. Na verdade, são políticas imperialistas e colonialistas disfarçadas. Em segundo lugar, a viagem demonstra a satisfação da diplomacia de Francisco: após assinar o Documento sobre a fraternidade humana com o Grande Imã sunita, o Papa foi à cidade santa xiita de Najaf, exclusivamente para se encontrar com o Grão Aiatolá Al Sistani, chefe espiritual de $60 \%$ da população iraquiana. Ao fazer esse gesto, diminuiu a pressão sobre o regime xiita do Irã, que os Estados Unidos e a Europa Ocidental - com menor intensidade -, tentam isolar. Esse é um verdadeiro exemplo de diplomacia preventiva, algo raro atualmente (Rondó, 2021).

A visita do Papa Francisco é outro símbolo desta aproximação do ocidente ao oriente e de duas grandes religiões. A mídia fez questão de retratar a imagem dos líderes em oração na Meca como sinal de que é possível orar juntos em prol da paz que ambos almejam realizar no mundo, além de veicular uma mensagem forte dos dois: "não instrumentalizem a religião" e "vocês são parte de nós, como nós somos parte de vocês".

\section{Considerações $F$ in a is}

Com este artigo, oferecemos uma leitura em perspectiva interdisciplinar das ciências da religião. Propusemos uma reflexão sobre o tema da interculturalidade, considerando o pensamento de Joseph Ratzinger sobre fé cristã, racionalidade e sentido de mundo. A partir das contribuições do seu raciocínio, demonstramos como a cultura asiática e islâmica influenciam na construção do sentido do mundo e, assim, as ideias de pretense universalidade da fé cristã e da racionalidade se revelaram como mera abstração. Além disso, não se deve desconsiderar a possibilidade de uma convivência plural, e o caminho proposto pelo Catolicismo e o Islamismo é a cultura do encontro e do diálogo.

Ao analisarmos politicamente o significado deste esforço religioso, ficou evidente para nós que o futuro das religiões passa pelo diálogo inter-religioso. Também ficou claro que os países que vivem uma democracia e reconhecem o sentido da laicidade precisam empenhar-se, por meio de uma atitude política, em garantir uma convivência plural que promova a cultura do encontro e do diálogo.

Os 20 anos posteriores ao 11 de setembro podem nos ensinar que os interesses do capital prevalecem em países poderosos e que haverá resistência dos oprimidos, os quais se organizaram até em grupos terroristas. Mas também, podemos observar que no empenho por aproximar ambos os lados, é possível um aprendizado mútuo, não sem desafios próprios da convivência, mas como um caminho que se faz pela cultura do encontro e do diálogo, na qual as religiões são anfitriãs deste processo.

\section{Referências}

Assunção, R. A. Bento XVI, a Igreja Católica e o "espírito da modernidade": uma análise do papa teólogo sobre o "mundo de hoje". São Paulo: Paulus, 2018. 
Barbosa, R. A. Os Estados Unidos pós 11 de setembro de 2001: implicações para a ordem mundial e para o Brasil. Revista Brasileira de Política Internacional, v. 45, n. 1, p. 72-91, 2002. Disponível em: https://www.scielo.br/pdf/ rbpi/v45n1/a03v45n1.pdf. Acesso em: 5 maio 2021.

Bauman, Z. Estranhos à nossa porta. Rio de Janeiro: Zahar, 2017.

Bellah, R. N. A nova consciência religiosa e a crise na modernidade. Religião e Sociedade, v. 13, n. 2, 1986.

Francisco, Papa. Carta Encíclica Fratelli Tutti: sobre a fraternidade e a amizade social. São Paulo: Paulinas, 2020a. (Coleção Voz do Papa). Disponível em: https://www.vatican.va/content/francesco/pt/encyclicals/documents/papafrancesco_20201003_enciclica-fratelli-tutti.html. Acesso em: 5 maio 2021.

Francisco, Papa. Carta Encíclica Laudato Si: sobre o cuidado com a Casa Comum. São Paulo: Paulina, 2015. (Coleção Voz do Papa). Disponível em: https://www.vatican.va/content/francesco/pt/encyclicals/documents/papafrancesco_20150524_enciclica-laudato-si.html. Acesso em: 5 maio 2021.

Francisco, Papa. Exortação apostólica pós-sinodal Querida Amazônia: ao povo de Deus e a todas as pessoas de boa vontade. São Paulo: Loyola, 2020b. Disponível em: https://www.vatican.va/content/francesco/pt/apost_exhortations/ documents/papa-francesco_esortazione-ap_20200202_querida-amazonia.html. Acesso em: 5 maio 2021.

Francisco, Papa; Al-Tayyeb, A. Documento sobre a fraternidade humana: em prol da paz mundial e da convivência humana. Abu Dabhi: Libreria Editrice Vaticana, 2019. Disponível em: https://www.vatican.va/content/francesco/ pt/travels/2019/outside/documents/papa-francesco_20190204_documento-fratellanza-umana.html. Acesso em: 5 maio 2021.

Giddens, A. Sociologia. 6. ed. Porto Alegre: Penso, 2012.

Guerreiro, S. Novos movimentos religiosos: o quadro brasileiro. Temas do ensino brasileiro. São Paulo: Paulinas, 2006.

Habermas, J.; Ratzinger, J. Dialética da secularização: sobre razão e religião. Aparecida: Ideias \& letras, 2007.

Hock, K. Introdução à Ciência da Religião. São Paulo: 2010.

Impagliazzo, M. Dois abraços e duas assinaturas: a viagem do Papa Francisco a Abu Dhabi. Unisinos, São

Leopoldo, 6 fev. 2019. Disponível em: https://www.ihu.unisinos.br/586454-dois-abracos-e-duas-assinaturas-aviagem-do-papa-fran\%20cisco-a-abu-dhabi. Acesso em: 5 maio 2021.

Manji, I. Minha briga com o Islã. O clamor de uma mulher muçulmana por liberação e mudança. São Paulo: W11, 2004.

Rondó, M. Visita do Papa ao Iraque desmascara algumas falácias. Carta Capital, São Paulo, 8 mar. 2021. Disponível em: https://www.cartacapital.com.br/opiniao/visita-do-papa-ao-iraque-desmascara-algumas-falacias/. Acesso em: 5 maio 2021.

Sorge, B. Breve curso de doutrina social. São Paulo: Paulinas, 2018.

Spadaro, A. La diplomazia di Francesco: la misericordia come processo politico. La Civilta Cattolica, v. 1, p. 209-226, 2016.

Tamayo, J. J. Hermano Islam. Madri: Trotta, 2019.

Tornielli, A. Papa: a Declaração que assinei com o Grão Imame aplica o Concílio. VaticanNews, Vaticano, 5 fev. 2019. Disponível em: https://www.vaticannews.va/pt/papa/news/2019-02/papa-francisco-abu-dhabi-coletiva-jornalistasretorno-roma.html. Acesso em: 5 maio 2021.

Como citar este artigo/How to cite this article

Boareto, J. A. O. Fé cristã, racionalidade e o "sentido do mundo" 20 anos após o 11 de setembro. Reflexão, v. 46, e215368, 2021. https://doi.org/10.24220/2447$6803 v 46 e 2021 a 5368$ 